\title{
KAJIAN SERAMIK DI TAPAK ARKEOLOGI DI BAHAGIAN PANTAI BARAT SABAH
}

\author{
(Ceramics Findings in Archeological Sites in the West Coast of Sabah)
}

NurulnatashaAzman
tasha890907@gmail.com

Pusat Penyelidikan Arkeologi Global, Universiti Sains Malaysia.

Sila rujuk: Nurulnatasha Azman. (2021). Kajian seramik di tapak arkeologi Bahagian Pantai Barat Sabah. Melayu: Jurnal Antarabangsa Dunia Melayu, 14(2), 201-218. http://doi.org. 10.37052/jm.14(2)no3

\begin{tabular}{|lllll}
\hline $\begin{array}{l}\text { Peroleh: } \\
\text { Received: }\end{array}$ 16/12/2020 & $\begin{array}{l}\text { Semakan: } \\
\text { Revised }\end{array}$ & 21/4/2021 & $\begin{array}{l}\text { Terima: } \\
\text { Accepted: 28/5/2021 }\end{array}$ & Terbit dalam talian: \\
& & & Published online: & 2/7/2021
\end{tabular}

\begin{abstract}
Abstrak
Terdapat penemuan seramik yang banyak di tapak arkeologi di bahagian pantai barat Sabah antaranya di Sungai Padang, Papar, Tuaran, Pulau Eno, Pulau Mengalum, Pulau Rusukan Besar dan Sungai Likas. Hasil kajian yang telah dilakukan mendapati kebanyakan seramik ini berasal dari pelbagai negara dan jangka masa yang berbeza-beza, seperti seramik China dari pelbagai dinasti, seramik dari Asia Tenggara seperti Vietnam, Thailand dan juga Kemboja. Di samping itu, seramik dari Eropah juga turut ditemui. Jangka masa seramik ini adalah dari zaman Dinasti Sung (Abad 10-13 Masihi), Dinasti Yuan (Abad 13-14 Masihi), Dinasti Ming (Abad 14 -17 Masihi), Dinasti Ch'ing (Abad 17-20 Masihi), Eropah (Abad 19-20 Masihi), Thailand (Abad 13- 15 Masihi) dan Vietnam (Abad 14 -15 Masihi). Jumpaan ini menunjukkan berkemungkinan pada suatu masa dahulu kawasan pantai barat Sabah merupakan kawasan perdagangan atau persinggahan yang penting bagi kapalkapal dagang berikutan penemuan seramik yang banyak dari pelbagai negara dan berlainan jangka masa.
\end{abstract}

Kata kunci: Seramik, perdagangan, Asia Tenggara, Sabah

(C) Dewan Bahasa dan Pustaka. 2021. This work is licensed under the term of the Creative Commons Attribution (CC BY) (http://creative commons.org/licenses/by/4.0/)

ISSN 1675-6460 e-ISSN 2682-8049 


\section{Abstract}

There are many ceramics findings in archeological sites in the west coast of Sabah, including Sungai Padang, Papar, Tuaran, Pulau Eno, Pulau Mengalum, Pulau Rusukan Besar and Sungai Likas. The results of this study found that most of these ceramics came from different countries and time periods, such as Chinese ceramics from various dynasties, and ceramics from Southeast Asia such as Vietnam, Thailand and Cambodia. In addition, ceramics from Europe were also found. The time periods of these ceramics are the Sung Dynasty (10th-13th century AD), Yuan Dynasty (13th-14th century AD), Ming Dynasty (14th-17th century AD), Ch'ing Dynasty (17th-20th century AD), Europe (19th-20th century AD), Thailand (13th15 th century $A D)$ and Vietnam (14th-15th century $A D)$. These findings indicate that in the past, the west coast of Sabah was an important trading or stopover area for merchant ships due to the large number of ceramics findings from various countries and different periods.

Keywords: Ceramics, trade, Southeast Asia, Sabah

\section{PENDAHULUAN}

Asia Tenggara dikenali sebagai Nanyang atau Nanhai (South Seas) dalam dokumen bersejarah China, dan sebagai timur India (East Indies) oleh Barat (Gungwu, 1960; Ko, 2015: 48). Kedudukan gugusan Melayu-Indonesia terletak di persimpangan jalan perdagangan yang sibuk di antara Benua India dan Tanah Besar China. Kedudukan Asia Tenggara yang strategik menjadikannya laluan perdagangan antara Barat dan Timur. Selain sebagai laluan perdagangan, pedagang dari Barat, Arab, India dan China singgah di Asia Tenggara bagi menunggu perubahan angin monsun untuk membawa mereka ke destinasi yang dituju (Nordin, 2008: 5). Perubahan arah tiupan angin ini dilihat sebagai faktor yang menyatukan para pedagang yang datang dari Lautan Hindi, kepulauan Melayu dan Tanah Besar China (Gungwu, 1960; Othman, 1978). Angin monsun yang pertama bermula pada bulan April dan angin Monsun yang kedua bermula pada bulan September (Rajah 1 dan Rajah 2). Pada awal bulan Mei, para pedagang dari India memulakan pelayaran mereka ke Asia Tenggara menuju ke timur, dan pada bulan Januari mereka kembali pulang ke India menggunakan angin timur laut membawa barangan dari China.

Pedagang dari China akan menetap di pelabuhan Asia Tenggara pada bulan Disember dan pulang ke China pada bulan Jun semasa peralihan monsun barat daya (Wheatley, 1961: xvii). Pelabuhan-pelabuhan yang ada di persisiran pantai ini memainkan peranan penting untuk memberikan kemudahan kepada pedagang dan 


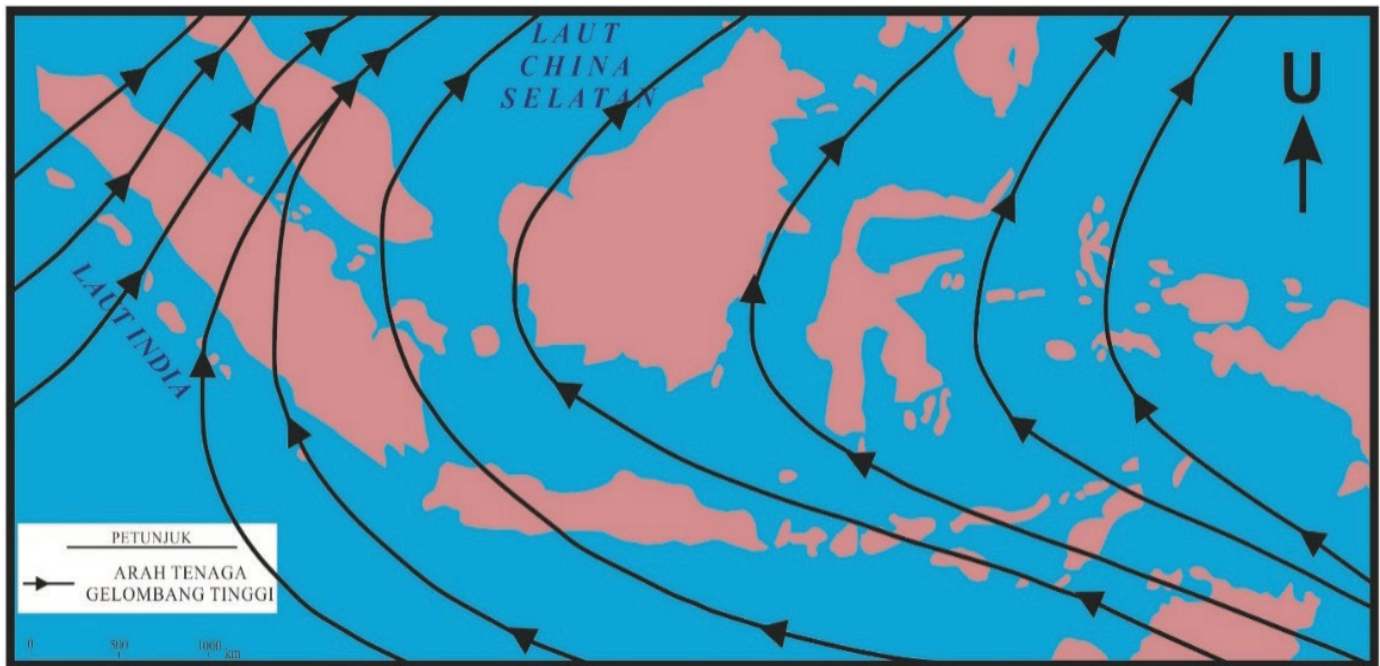

Rajah 1 Peta pergerakan angin monsun timur laut.

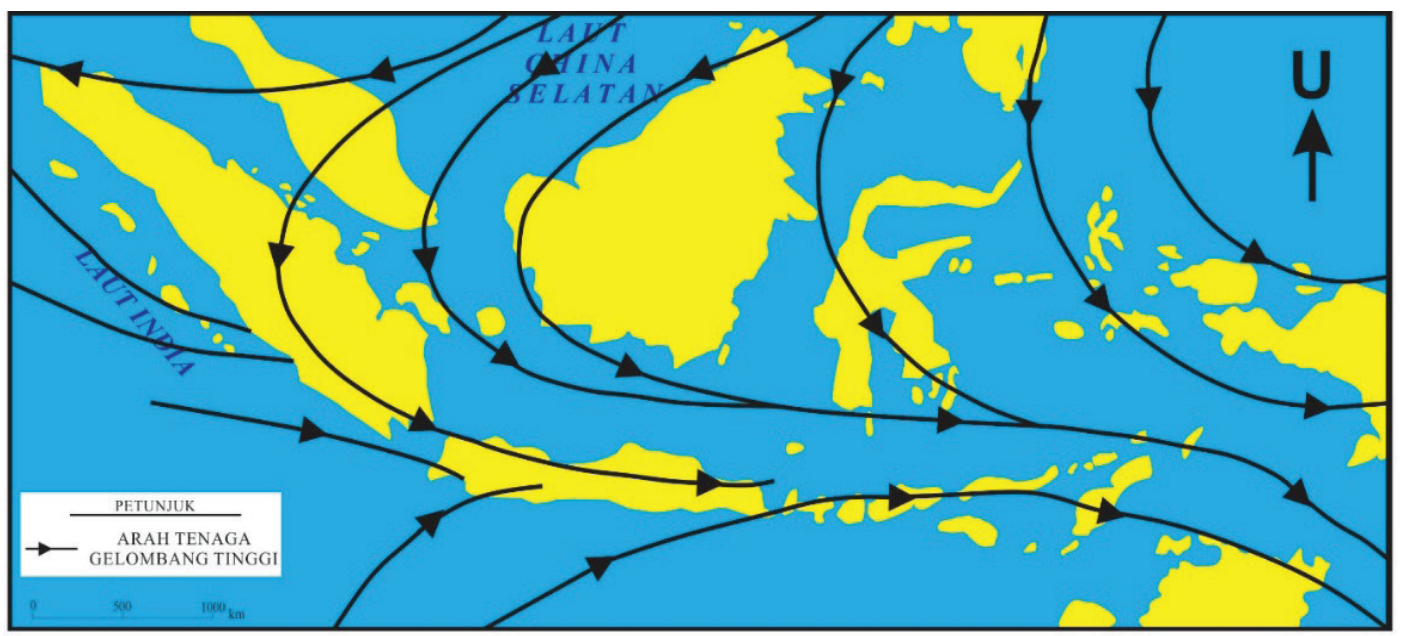

Rajah 2 Peta pergerakan angin monsun barat daya

aktiviti perdagangan. Malah, kepulauan Asia Tenggara ini sangat kaya dengan hasil hutan, rempah ratus dan sebagainya yang menjadi komoditi perdagangan utama pada waktu itu (Reid, 1998). Oleh itu, kerajaan dan pelabuhan yang wujud di Asia Tenggara penting sebagai pusat pembekal barangan tempatan untuk ditukar dengan produk luar yang dibawa oleh pedagang khususnya seramik (Reid, 1998; Lockard, 2010). 
Pada abad ketujuh Masihi, perdagangan semasa Dinasti Tang semakin berkembang dan kemunculan kerajaan baharu yang mengawal perdagangan di Laut China Selatan. Jumpaan di tapak arkeologi di Asia Tenggara mencadangkan bahawa pada abad ke-7 Masihi ini, seramik dieksport secara meluas menggunakan perdagangan maritim (Ko, 2015: 51). Jumpaan kapal karam Belitung, iaitu kapal dagang Arab dengan seramik Dinasti Tang membuktikan kewujudan perdagangan antara Selatan China dan Arab khususnya melalui Asia Tenggara (Nordin, 2008; Flecker, 2013). Di samping itu, terdapat pelabuhan baharu di bahagian pantai barat Borneo yang menjadi tumpuan pedagang, iaitu Boni (Po-ni). Pertama kali muncul dalam catatan China pada abad kesembilam Masihi. Sesetengah sejarawan merujuk Boni sebagai kerajaan awal di Brunei.

Kajian arkeologi di Brunei mencadangkan bahawa kerajaan Boni ini aktif menjalankan perdagangan pada masa kerajaan Tang di Delta Sungai Sarawak. Catatan Zhao Rukua pada tahun 1225 Masihi menyatakan bahawa pelabuhan Boni lengkap dengan kemudahan untuk para pedagang dan layanan yang baik (Andaya \& Andaya, 2001: 31). Pada masa yang sama, perdagangan laut antara selatan China dan Asia Tenggara melonjak pada abad ke-10 Masihi. Pada zaman Dinasti Sung, perkembangan perusahaan tembikar begitu pesat dan menjadikannya antara bahan dagangan utama China ke luar negeri (Karim, 2004; 17, Baszley \& Bilcher, 2009: 151, Wade, 2009: 222). Banyak kapal karam yang ditemui di perairan Asia Tenggara antara Simpang Mengayau di Kudat, Pulau Buaya dan Intan di Laut Jawa, Nanhai 1 dan Huaguangjiao 1 berdekatan Pulau Hainan yang menunjukkan kepesatan perdagangan pada masa ini, yang merupakan laluan perdagangan pada zaman Dinasti Tang, Sung dan Yuan di rantau Borneo dan kepulauan Filipina.

Kemajuan perdagangan antara China dan India berterusan pada abad ke-11 dan abad ke-12 Masihi semasa pemerintahan Dinasti Sung. Terdapat banyak penemuan seramik Sung di Pengkalan Bujang, Kampung Sungai Mas, Pulau Tioman dan Takuapa yang menunjukkan wujudnya transaksi komoditi yang aktif di antara kotakota pesisir pantai Semenanjung Tanah Melayu (Nazaruddin \& Nasha, 2015: 24). Pada abad ke-13 dan ke-14 Masihi, China telah dikuasai oleh Mongol di bawah Dinasti Yuan, Majapahit pada masa ini menguasai Pulau Jawa, Sumatera, Tanah Melayu, Borneo, Sulawesi, Madura, Bali dan wilayah lain di Nusantara. Pada masa ini juga, seramik China menghadapi persaingan daripada seramik Sukhotai dan Sawankhalok Thailand, serta seramik Vietnam yang juga berkembang pada abad ini (Ko, 2015: 63). Penemuan kapal karam Jawa di Laut Jawa, Turiang dan Longquan di Semenanjung Tanah Melayu menunjukkan kesinambungan perdagangan di Asia Tenggara. 
Perdagangan China di Laut China Selatan dan Lautan Hindi mengalami kemuncaknya pada abad ke-15 Masihi hingga awal abad ke-18 Masihi semasa zaman pemerintahan Dinasti Ming hingga awal Dinasti Ching (Hall, 2010: 2) Jalan perdagangan pada awal abad ke-15 Masihi terbahagi kepada dua yang meliputi laluan barat dan timur. Laluan barat menyusuri Champa menuju ke Semenanjung Tanah Melayu ke utara Jawa, manakala jalan timur pula meliputi perjalanan menuju ke Kepulauan Ryukyu, Filipina (Luzon), Sulu dan Borneo (Brunei) (Fox, 2003: 76). Di Borneo, pada awal abad ke-15 Masihi, Brunei menjadi tumpuan para pedagang dan merupakan salah satu kerajaan yang mendapat pelindungan secara langsung daripada China di samping bantuan Orang Laut dalam urusan di pelabuhan. Para pedagang singgah di Brunei pada musim monsun barat daya sebelum meneruskan perjalanan mereka. Kapal dagang dari China pula, berdagang dari pantai Vietnam dan singgah di Brunei semasa monsun timur laut. Tambahan pula, Brunei juga merupakan pelabuhan penting bagi pedagang China yang belayar menyusuri pulau-pulau di utara Filipina dan kepulauan Sulu. Dari Brunei, mereka pulang ke China atau meneruskan perjalanan ke bahagian lain di Asia Tenggara (Hall, 2010: 6-8; Andaya \& Andaya, 2001: 60). Brunei menerima pengaruh Islam antara tahun 1514 dan 1521 dan pada penghujung abad ke-15 Masihi, pihak Sepanyol menyerang Brunei dan menguasai pelabuhannya. Oleh itu, ditemui jumpaan seramik yang banyak di bahagian barat pantai Sabah ini berkemungkinan dipengaruhi oleh kepesatan pelabuhan Brunei pada abad ke-15 Masihi.

\section{ANALISIS SERAMIK YANG DIJUMPAI DI BAHAGIAN PANTAI BARAT SABAH}

Ekskavasi yang dijalankan oleh Bahagian Arkeologi, Jabatan Muzium Sabah telah menjumpai banyak seramik di tapak arkeologi di Bahagian Pantai Barat Sabah. Seramik yang dianalisis ini ialah koleksi seramik di Bahagian Arkeologi, Jabatan Muzium Sabah sama ada diperoleh melalui ekskavasi, jumpaan permukaan dan sebagainya. Analisis yang dilakukan adalah secara kualititatif dan kuantitatif. Analisis lapangan ini hanya dilakukan di stor simpanan Bahagian Arkeologi dan di Bahagian Konservasi, Jabatan Muzium Sabah bagi seramik dari kapal karam Simpang Mengayau yang masih dalam proses konservasi. Analisis ini bertujuan untuk mengelaskan seramik yang ada mengikut ciri-ciri tertentu seperti jenis seramik, pentarikhan, motif hias, negara asal dan warna, serta direkodkan menggunakan borang analisis seramik yang telah disediakan agar data yang diambil adalah seragam dan sistematik. Analisis kuantitif ini dilalukan bagi mengenal pasti jenis seramik yang terdapat dalam simpanan Muzium 

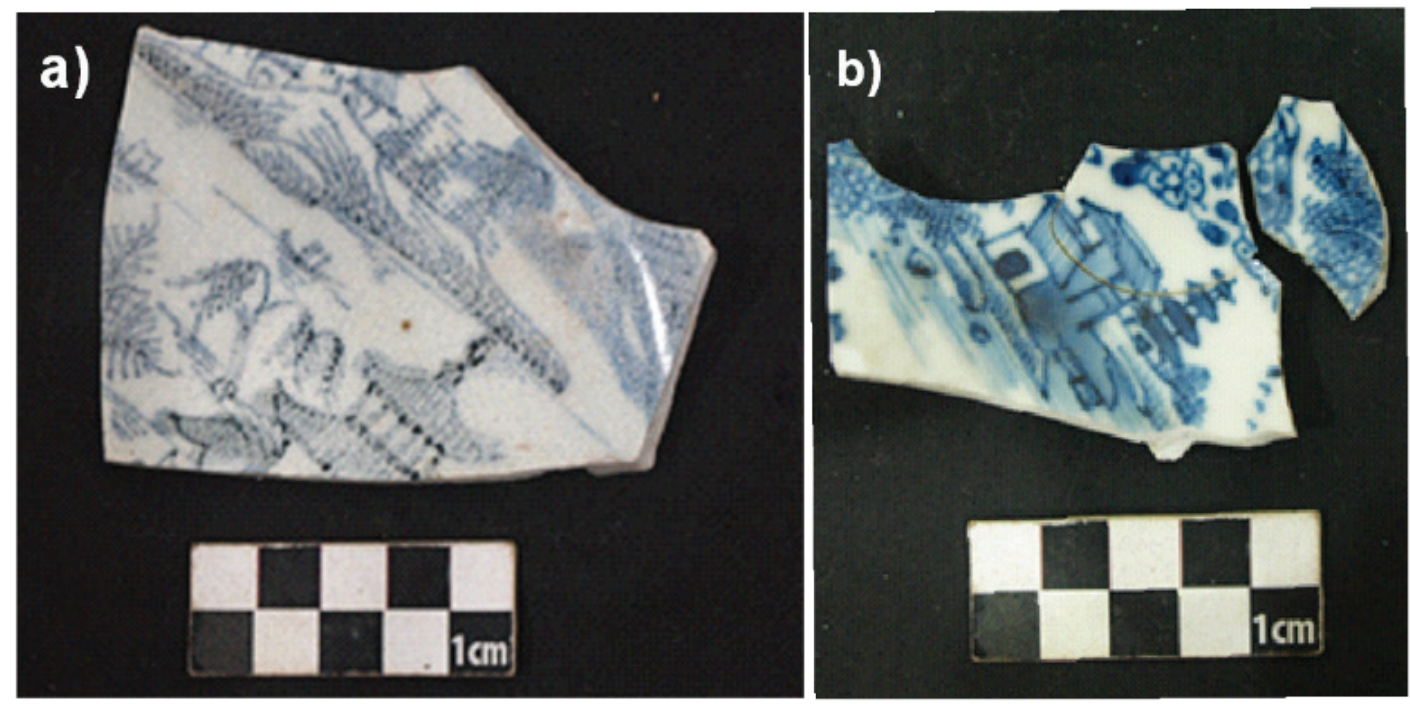

Rajah 3 Pecahan seramik yang dijumpai dan dianalisis bagi mendapatkan data dalam kajian ini.

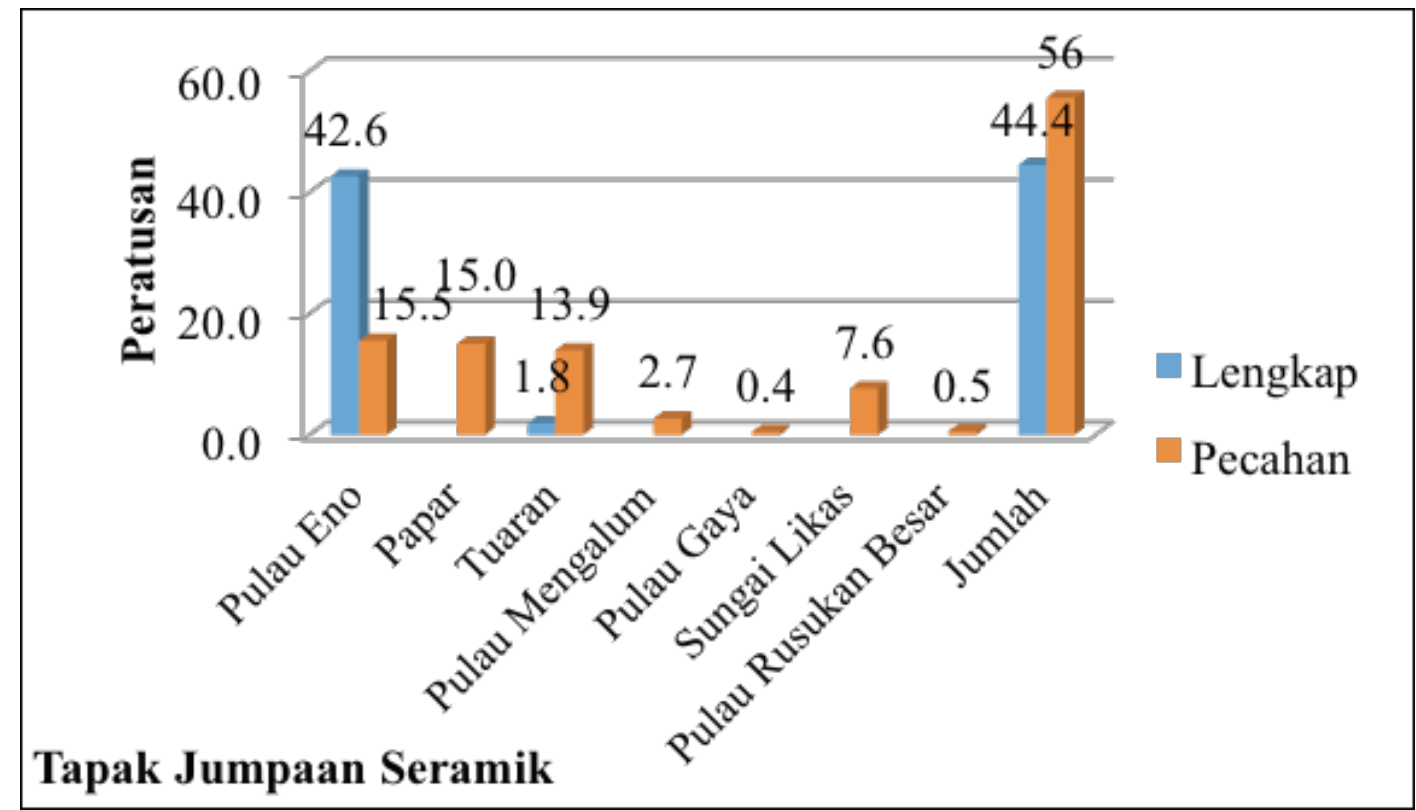

Rajah 4 Jumpaan seramik di bahagian barat pantai Sabah. 


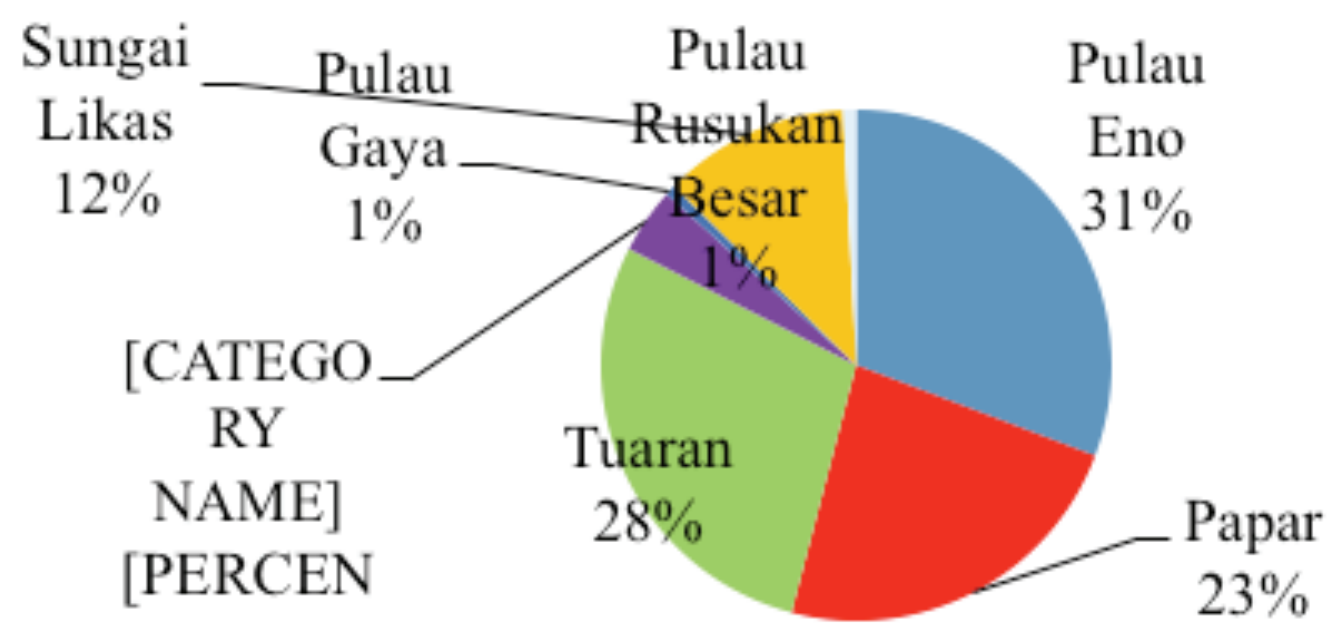

Rajah 5 Jenis seramik yang dijumpai di bahagian pantai barat Sabah.

Sabah. Terdapat kriteria tertentu yang perlu diambil kira semasa analisis ini dijalankan, iaitu berat dan bilangan setiap seramik yang dianalisis akan direkodkan bagi tujuan penyimpanan. Bagi pecahan seramik, terdapat beberapa kaedah yang digunakan antaranya termasuklah pengiraan pecahan dan berat. Hal sedemikian dilaksanakan kerana setiap pecahan yang dianalisis dikira sebagai satu pecahan daripada seramik yang lain tanpa mengira sama ada pecahan itu boleh disambungkan ataupun tidak seperti Rajah 3.

Di samping itu, penggunaan istilah seramik minimum dan maksimum digunakan dalam kajian ini. Seramik "minimum" bermaksud setiap pecahan itu dikira sebagai satu seramik yang sama sehinggalah terbukti bukan daripada seramik yang sama. Seramik "maksimum" pula ialah setiap pecahan itu dikira sebagai seramik yang berbeza sehinggalah dibuktikan bahawa pecahan itu daripada seramik yang sama (Orton, 1989; 94-97). Namun demikian, terdapat kelemahan dan bias dalam penggunaan kaedah berat ini disebabkan oleh seramik yang mempunyai bentuk yang lebih besar kebiasaannya lebih berat berbanding seramik yang lebih kecil (Orton, 1989: 96). Namun demikian, kajian lanjutan perlu dilakukan untuk mengenal pasti kiln atau dapur pembuatan setiap sampel seramik berkenaan. Walau bagaimanapun, sampel yang terlalu kecil sukar untuk dikenal pasti kiln yang menghasilkan seramik berkenaan.

Hasil analisis menunjukkan seramik yang paling banyak ditemui di bahagian barat Sabah adalah dari tapak Pulau Eno, iaitu 5685g, diikuti dengan Tuaran (5256g), Papar 


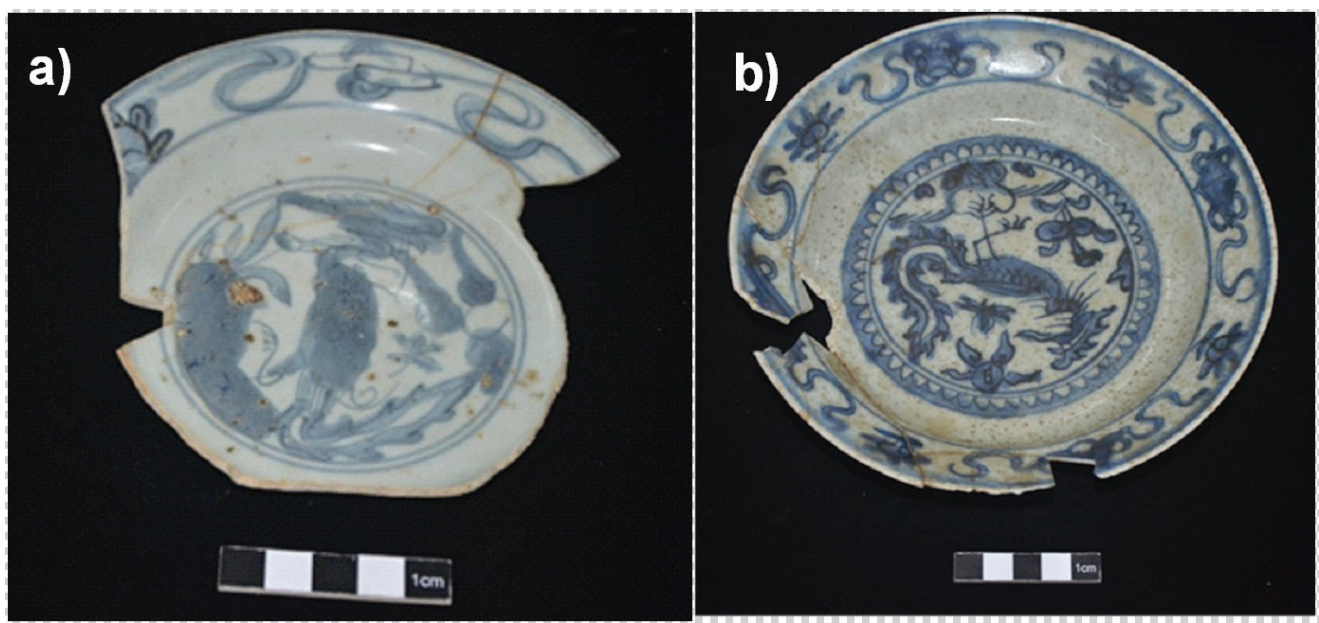

Rajah 6 Antara seramik biru dan putih yang dijumpai di tapak-tapak arkeologi di Pantai Barat Sabah.

(4304g), Sungai Likas (2182g), Pualau Mengalum (765g), Pulau Rusukan Besar (155g) dan Pulau Gaya (125g). Di samping itu, peratusan keseluruhan jumpaan seramik, Pulau Eno sebanyak 31\%, diikuti tapak Tuaran (28\%), Papar (23\%), Sungai Likas (12\%), Pulau Mengalum (4\%), Pulau Rusukan Besar (1\%) dan akhir sekali tapak Pulau Gaya dengan 1\% (Rajah 3.3). Hanya di Pulau Eno dan Tuaran sahaja telah ditemui seramik yang lengkap. Secara keseluruhannya, 56\% seramik jenis pecahan manakala $44.4 \%$ pula jenis lengkap seperti dalam Rajah 4.

Analisis jenis seramik yang telah dilakukan menunjukkan bahawa terdapat tujuh jenis seramik di bahagian pantai barat Sabah ini yang terbanyak ialah porselin biru putih (Rajah 6) dan diikuti oleh lain-lain tembikar batu. Tembikar batu bergilap hitam adalah yang paling sedikit, iaitu $0.1 \%$ sahaja (Rajah 5). Hasil daripada analisis ini menunjukkan bahawa bahagian barat Sabah mempunyai lebih banyak jumpaan jenis porselin biru putih berbanding seramik yang lain.

\section{JANGKA MASA SERAMIK DAGANGAN YANG DIJUMPAI DI BAHAGIAN PANTAI BARAT SABAH}

Bagi melihat dengan lebih teratur jangka masa perdagangan seramik di Sabah, maka setiap seramik ini dibahagikan mengikut tahun pembuatannya. Di bahagian pantai barat Sabah ini, jangka masa seramik yang dapat dikenal pasti berlangsung 


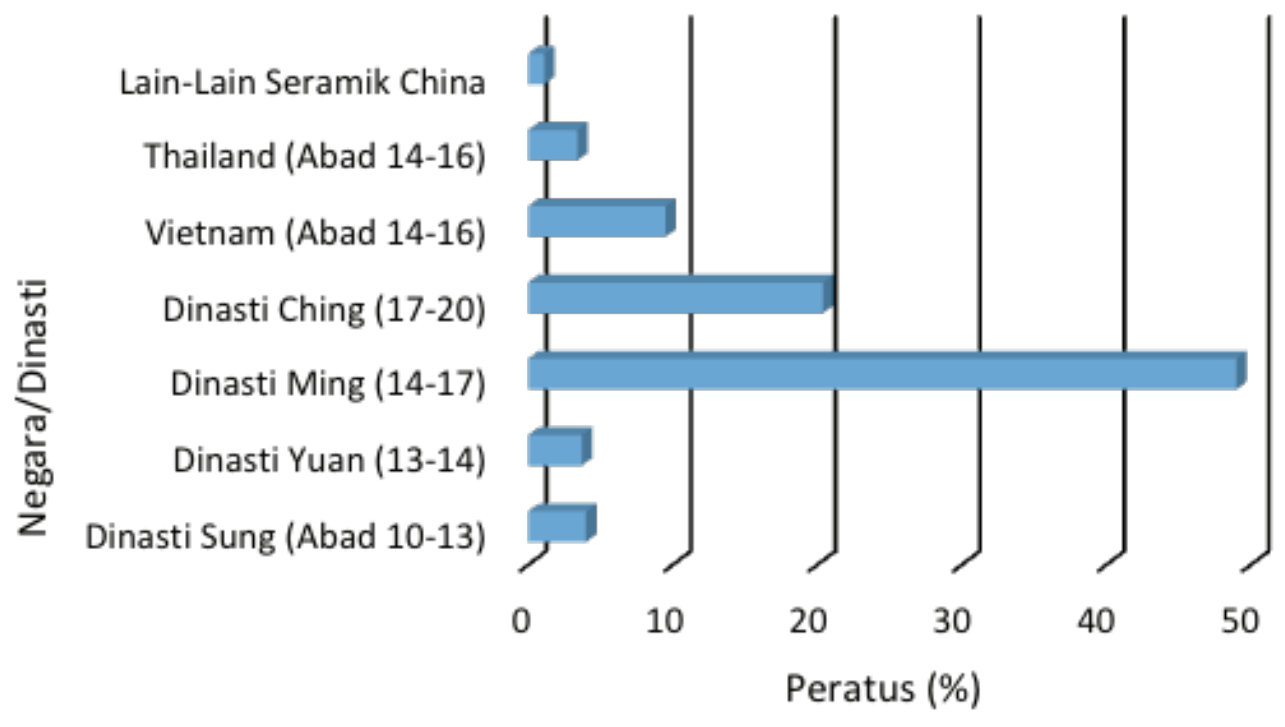

Rajah 7 Rajah menunjukkan jangka masa perdagangan seramik di bahagian pantai barat.

dari abad ke-10 hingga abad ke-20 Masihi. Kebanyakan seramik yang ditemui ialah seramik China dari zaman Dinasti Ming (abad 14-17 Masihi) diikuti dengan Dinasti Ching (abad 17-20 Masihi), seramik Eropah (abad 19-20 Masihi), seramik China Dinasti Yuan (abad 13-14 Masihi), seramik Vietnam (abad 14-15 Masihi), seramik Thailand (abad 13-15 Masihi) dan akhir sekali seramik China Dinasti Sung (abad 10-13 Masihi). Seramik dari kepulauan Asia Tenggara pula seperti Vietnam dan Thailand dikenal pasti bermula kira-kira pada penghujung abad ke-14 Masihi bersamaan dengan zaman Dinasti Ming di China. Jumlah dan peratusan jangka masa bagi seramik yang ditemui di pantai barat Sabah dapat dilihat pada Rajah 7.

Seramik yang telah ditemui di bahagian pantai barat Sabah ini berasal daripada pelbagai jangka masa yang menunjukkan tempoh dan kemuncak jangka masa itu berlangsung. Taburan seramik yang dimaksudkan ialah tempoh masa atau pentarikhan seramik dagangan yang dijumpai di tapak arkeologi. Secara keseluruhannya, hasil analisis yang telah dilakukan menunjukkan bahawa seramik terawal yang ditemui ialah seramik China dari zaman Dinasti Sung, iaitu abad ke-10 hingga ke-13 Masihi. Walau bagaimanapun, terdapat jumpaan seramik dari China di Borneo yang bertarikh lebih awal, iaitu zaman Dinasti Tang di Santubong (Harrisson \& O'Connor, 1969; Ipoi, 1998; Taçon et al., 2010). 
Hal ini menunjukkan bahawa berkemungkinan Sabah telah dikunjungi oleh para pedagang seawal abad ke-10 Masihi atau lebih awal lagi. Namun begitu, melalui jumpaan ini menunjukkan bahawa kepesatan perdagangan seramik dari China ke Sabah bermula pada abad ini. Hall (1992) pula berpendapat bahawa pada abad ke10, seramik ialah barang dagangan China yang utama ke pasaran luar negeri.

Berdasarkan Rajah 7 di atas, jumpaan seramik yang paling banyak ialah seramik China zaman Dinasti Ming di bahagian barat Sabah. Hal ini menunjukkan bahawa kawasan ini menerima pengaruh dan interaksi yang tinggi dalam jangka masa ini. Seramik pada zaman dinasti Ming ini juga turut dijumpai di tapak arkeologi lain di Asia Tenggara. Antaranya termasuklah di Malaysia, Sumatera, Jawa, Kepulauan Sulawesi, Filipina, dan Borneo (Harrisson \& Harrisson, 1971) bersama-sama dengan seramik dari Vietnam dan Thailand yang bertarikh pada abad ke-14 hingga abad ke16 Masihi yang didagangkan dalam pasaran rantau Asia Tenggara pada masa yang sama. Seramik Thailand sama ada Sawankhalok atau Sukhotai mula diperdagangkan ke pasaran Asia Tenggara semasa zaman awal Dinasti Ming (Guy, 1993). Kebanyakan seramik tersebut dieksport ke pasaran luar melalui pelabuhan Ayuthaya yang terletak berhampiran Teluk Thailand dan Laut Andaman (Guy, 1993: 8; Sukkham, 2014: 2-3). Kerajaan Ayuthaya diasaskan pada tahun 1351 Masihi dan menjadi salah satu kerajaan Thai yang kuat. Kerajaan ini telah menjalankan aktiviti perdagangan dengan kerajaan-kerajaan awal di Asia Tenggara, India, China serta menjadi pelabuhan yang penting pada abad ke-15 Masihi. Bahagian barat Sabah, seramik Ming lebih tertumpu di tapak Sungai Likas, Pulau Eno, Tuaran dan Papar. Jumpaan-jumpaan ini menunjukkan bahawa di bahagian barat ini interaksi perdagangan yang berlaku paling banyak adalah pada zaman Dinasti Ming (abad ke-14 sehingga abad ke-17 Masihi). Pada masa yang sama, interaksi perdagangan yang pesat ini juga disebabkan oleh wujudnya kerajaan awal, antaranya termasuklah Banjarmasin, Sundakana dan Hutei di bahagian Selatan Borneo. Banjarmasin menjadi pelabuhan penting membekalkan lada hitam sebagai eksport utamanya serta emas dan madu kepada para pedagang. Pelabuhan ini juga menjalinkan hubungan perdagangan yang penting dengan Dutch East India (VOC) dengan membekalkan lada hitam untuk pasaran Eropah dan Timur Tengah (Fong, 1984).

Hasil analisis yang telah dilakukan menunjukkan bahawa seramik terawal yang ditemui ialah seramik China dari zaman Dinasti Sung, iaitu abad ke-10 hingga ke13 Masihi. Terdapat juga jumpaan seramik dari dinasti yang lain seperti Dinasti Yuan, Ming dan Ch'ing. Seramik lain China merujuk seramik China tetapi tidak dapat dikenal pasti jangka masanya. Selain itu, seramik dari Asia Tenggara, iaitu dari Vietnam, Khmer dan Thailand turut ditemui di tapak arkeologi di Sabah. Seramik 
dari Vietnam lebih banyak ditemui berbanding dengan seramik dari Thailand dan Khmer. Seramik dari Eropah juga turut ditemui. Lain-lain seramik bermaksud seramik yang tidak dapat dikenal pasti disebabkan oleh keadaan pecahan yang terlalu kecil sehingga menyukarkan pengenalpastian dilakukan.

Seramik dari Asia Tenggara turut ditemui di tapak arkeologi di Sabah. Seramik Asia Tenggara ini merujuk seramik dari Vietnam, Thailand sama ada Sukhotai atau Sawankhalok dan Khmer (Kemboja). Jumpaan seramik dari Asia Tenggara ini dijumpai di beberapa tapak arkeologi terutamanya di bahagian barat Sabah. Secara umumnya, Asia Tenggara juga menghasilkan produk seramiknya sendiri selain seramik import dari China. Tambahan pula, dalam kajian ini seramik dari Asia Tenggara khususnya Thailand, Vietnam dan Khmer di temui di tapak-tapak arkeologi di Sabah. Antara negara yang menghasilkan seramik di Asia Tenggara ialah Vietnam, Thailand, Khmer (Kemboja) dan Burma. Seramik dari Thailand dikenali juga sebagai Siamese ware. Siam ialah nama asal bagi Thailand sebelum mendapat kemerdekaan daripada British. Bengkel penghasilan seramik di Thailand ini dibahagikan kepada kawasan utara, tengah dan selatan. Seramik Thailand merujuk seramik yang diperoleh dari dua bengkel pembuatan tradisional, iaitu Sawankhalok dan Sukhothai (Sisatchanalai). Bengkel pembuatan seramik ini beroperasi kira-kira pada abad ke-14 hingga ke-16 Masihi (Pitiphat, 1992).

Sukhotai ialah ibu negeri yang wujud pada abad ke-13 Masihi hingga abad ke-14 Masihi. Penghasilan seramik Sukhotai ini diasaskan dengan teknik dan pembuatan seramik dari China berikutan hubungan diplomatik antara Raja Ram Kamheng dengan China (Brown, 1978; Scott \& Stratton, 1987). Secara umumnya, Satratton mengklasifikasikan seramik Sukhotai melalui tekstur berbutir putih yang terdapat pada badan seramik. Tanah liat kelihatan tebal, kasar dengan partikel halus berwarna putih bertaburan pada badan seramik. Kebiasaannya gilapan berwarna kuning pucat atau hijau melapisi corak hiasan dan badan seramik kecuali tapak (Scott \& Stratton, 1987). Selain itu, terdapat tanda pembakaran (spur marks) di tengah-tengah seramik disebabkan oleh penggunaan penyokong ketika proses pembakaran dilakukan bagi menggelakkan seramik melekat antara satu dengan yang lain (Scott \& Stratton, 1987; Pitiphat, 1992). Seramik dari bengkel pembuatan Sukhotai dibahagikan kepada beberapa jenis seramik yang utama, iaitu seramik monokrom berwarna putih, seramik hitam bergilap (underglaze black wares) dan seramik bergilap berwarna coklat (underglaze brown wares). Seramik monokrom tidak bercorak, berwarna putih dan mempunyai gilapan yang jernih dan nipis merupakan seramik yang paling banyak dihasilkan di Sukhotai (Pitiphat, 1992). 
Tapak pembuatan seramik Sawankhalok pula terletak berdekatan wilayah Sisatchanalai atau kerajaan lama Sukhotai (Scott \& Stratton, 1987: Pitiphat, 1992: Brown, 1988) yang beroperasi kira-kira pada penghujung abad ke-14 Masihi (1350) hingga abad ke-16 Masihi (1584 Masihi). Terdapat tiga bengkel pembuatan seramik yang penting, iaitu Ban Ko Noi, Pa Yang dan Tukuta (Scott \& Stratton, 1987). Ciri-ciri utama pada seramik Sawankhalok ialah material dalam pembuatan seramik Sawankhalok ini kelihatan lebih padat, berat dan butiran berwarna hitam kelihatan pada badan seramik (Scott \& Stratton, 1987). Pada bahagian dasar seramik Sawankhalok terdapat kesan lingkaran (ring) akibat penggunaan penyokong semasa proses pembakaran seramik (Scott \& Stratton, 1987). Seramik Sawankhalok ini juga menerima pengaruh tradisi seramik dari China. Seramik dari Sawankhalok ini kebanyakannya seladon dan menyerupai penghasilan seladon dari tapak Longquan, wilayah Zhejiang

\section{JUMPAAN SERAMIK DI SABAH DAN KEPESATAN PELABUHAN BRUNEI PADA ABAD KE-15 MASIHI}

Pada zaman Dinasti Ming, perdagangan antara kepulauan Borneo dan China berkembang. Hasil perkembangan perdagangan ini telah menyebabkan pelabuhan Brunei menjadi tumpuan para pedagang untuk berlabuh. Brunei juga menjadi pusat pelabuhan utama di antara Sulu dan Brunei yang menyebabkan pantai Sabah semakin popular dan disinggahi oleh pedagang China setiap masa (Harrisson \& Harrisson, 1971). Pada masa ini juga, kegiatan ekonomi yang penting ialah perdagangan. Pedagang dari China menukar seramik untuk mendapatkan barang hasil tempatan dan bekalan untuk belayar. Penduduk tempatan pula akan menukar hasil hutan dan memasarkan produk keluaran mereka (Harrisson \& Harrisson, 1971). Oleh yang demikian, tidak hairanlah banyak jumpaan seramik yang ditemui di tapak-tapak arkeologi di Sabah. Seramik yang banyak ditemui ialah seramik biru putih bertarikh zaman Dinasti Ming ditemui di tapak arkeologi di Sabah seperti peta dalam Rajah 8. Di tapak seperti Tuaran, Papar, Pulau Gaya, Pulau Eno, Pulau Gaya, Sungai Likas telah ditemui artifak seramik yang kebanyakannya seramik biru putih yang sememangnya popular pada zaman ini. Tambahan pula, jumpaan kapal karam Brunei di Teluk Brunei yang bertarikh zaman Dinasti Ming juga membuktikan bahawa kawasan perairan Sabah dan Brunei dilalui oleh kapal-kapal dagang dari serata Asia Tenggara dan kawasan yang lain.

Selain tapak arkeologi di Sabah, seramik juga dijumpai di Brunei, iaitu di Sungai Limau Manis, Sungai Lumut dan Terusan Kupang. Sungai Limau manis merupakan 


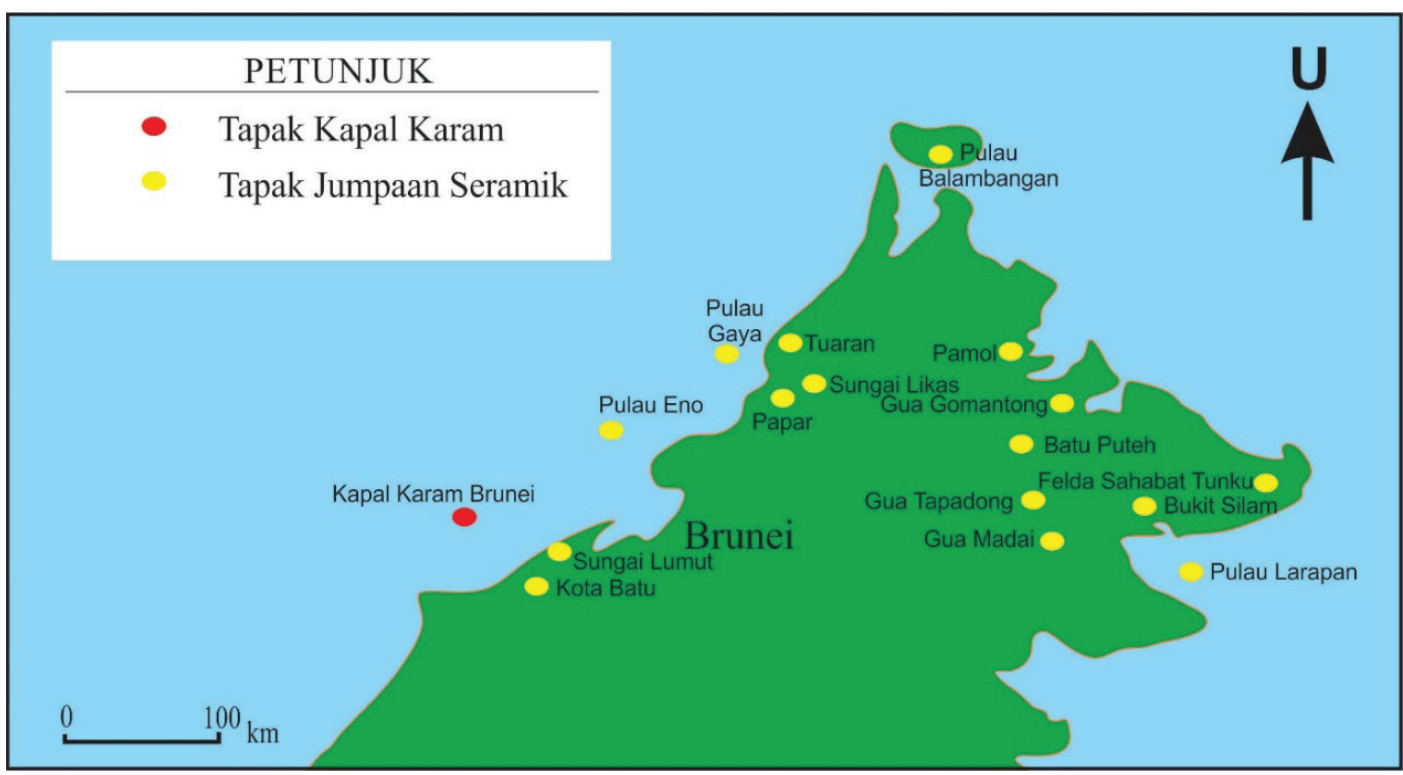

Rajah 8 Peta tapak jumpaan seramik di Sabah dan Brunei pada zaman dinasti Ming (abad ke14 hingga abad 17 Masihi)

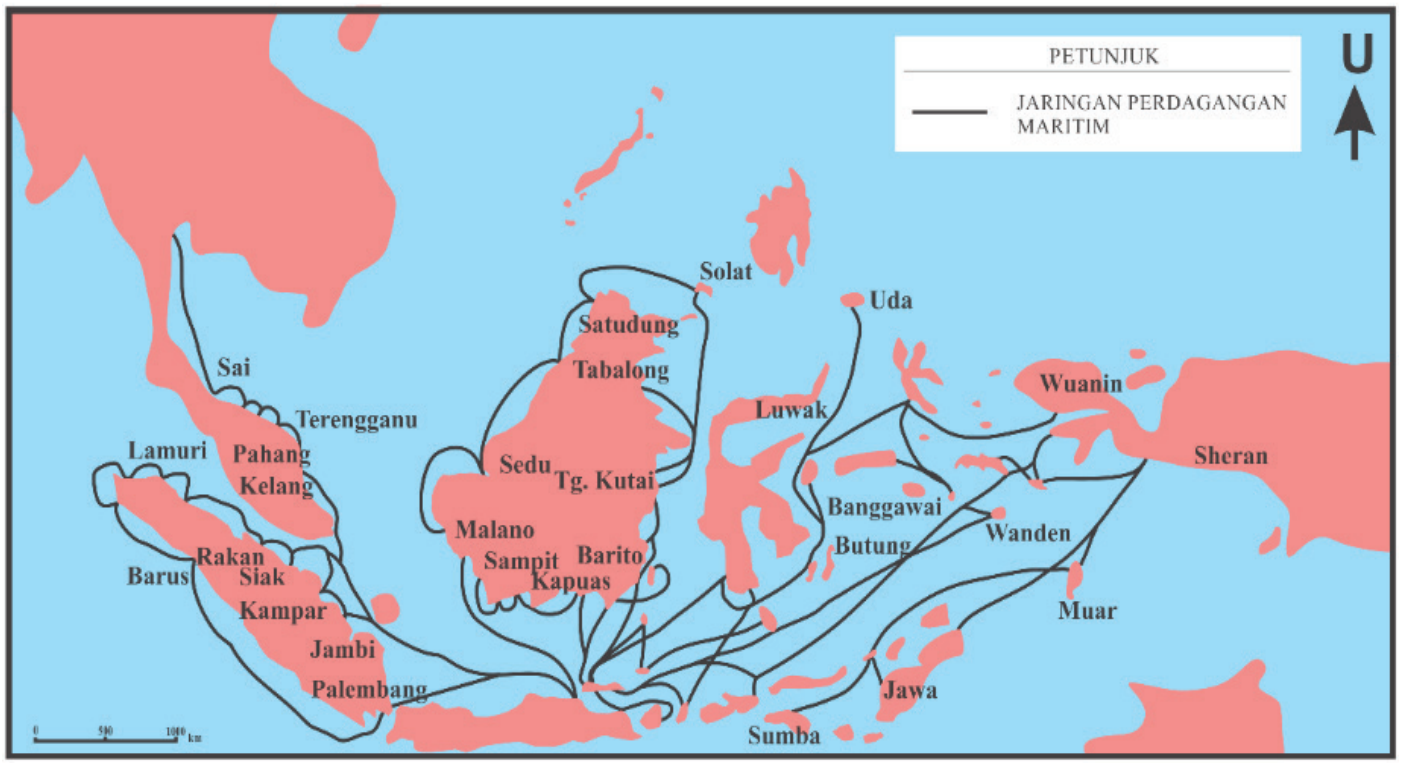

Rajah 9 Peta laluan perdagangan di Kepulauan Indonesia pada abad ke-14 Masihi (Sumber: Lapian, 1984) 
tapak terbuka dengan jumpaan seramik yang banyak bertarikh zaman dinasti Sung (abad ke-10 hingga ke-13 Masihi). Di Terusan Kupang pula kebanyakan artifak yang dijumpai ialah seramik China abad ke-14 Masihi, iaitu zaman dinasti Yuan dan di tapak Sungai Lumut pula, terdapat banyak jumpaan artifak seperti tembikar batu, porselin, manik, pecahan kaca, gangsa dan damar bertarikh zaman dinasti Ming (Miksic, 2013) seperti peta dalam Rajah 9.

Kota Batu menjadi pusat perlabuhan untuk persinggahan bagi kapal-kapal dari Barat dan Timur seperti China, Arab, Sepanyol, Portugis dan sebagainya (Tassim: 2013). Selain pedagang dari luar, Kota Batu juga dikunjungi oleh peniaga-peniaga dari Pahang, Terengganu, Kelantan, Siam, Kemboja dan Jawa. Kedatangan peniagapeniaga tersebut telah memakmurkan perdagangan di Brunei dan pantai barat Sabah. Kapal-kapal dagang asing berlabuh di pelabuhan di pantai barat Sabah sebelum meneruskan perjalanan ke Kota Batu bagi mendapatkan bahan tempatan di samping untuk memasarkan bahan dagangan mereka di pasaran tempatan. Kajian arkeologi yang dijalankan di tapak ini telah menemukan kira-kira 6,230 pecahan seramik yang terdiri daripada porselin dan tembikar batu. Tembikar China meliputi kira-kira 66.5\% daripada keseluruhan jumpaan seramik. Selain jumpaan seramik, dijumpai juga batu nisan, bahan kayu, wang syiling dan sebagainya (Pelita Brunei, 2015: 10-11). Antara jenis seramik yang telah ditemui termasuklah seramik buatan tempatan (tembikar tanah liat) dan luar negeri. Seramik jenis porselin dan tembikar tanah ialah buatan China, Siam dan Indo-China. Sebahagian besar seramik yang ditemui ini ialah seramik bertarikh zaman Dinasti Sung (960-1279 Masihi) dan Dinasti Ming (1368-1643) Masihi (Tassim; 2013). Kemunculan bahan-bahan import daripada Dinasti Ming (kurun ke-14 hingga ke-16 Masihi) apabila penempatan Kota Batu berada di pemerintahan Sultan Bolkiah dan penggantinya. Kota Batu juga telah menjadi pusat perdagangan dan penyebaran agama Islam yang gemilang pada abad ke-15 dan 16 Masihi. Malah Brunei pada abad ke-16 Masihi dianggap sebagai pengganti Melaka setelah ditawan oleh Portugis pada tahun 1511 (Hall, 1995).

Seramik yang dijumpai di tapak arkeologi di Sabah dan Brunei mempunyai persamaan, iaitu seramik biru putih yang dihasilkan pada zaman dinasti Ming. Oleh yang demikian, jumpaan seramik di Sungai Limau Manis, Kota Batu, Sungai Lumut dan Terusan Kupang menunjukkan bahawa kawasan ini telah meneruskan kesinambungan perdagangan dari zaman Dinasti Sung, Yuan hingga ke Dinasti Ming. Di samping itu, faktor lain yang membantu kepesatan berdagangan di Sabah juga ialah kepentingan Banjarmasin yang terletak di bahagian selatan Borneo yang menjadi emporia bagi perdagangan rempah ratus antara kepulauan Indonesia. Banjarmasin juga menjadi pelabuhan penting bagi pedagang dari China dan Jawa untuk berhubung dan berdagang 
dengan Thailand, Kemboja, Selatan Vietnam dan kepulauan Maluku (Hall, 1995; Metussin \& Shariffuddin, 1978) (Rajah 9).

\section{KESIMPULAN}

Secara keseluruhannya seramik dagangan yang ditemui di Sabah ialah seramik berbentuk lengkap dan pecahan. Analisis yang dijalankan di Bahagian Arkeologi, Jabatan Muzium Sabah telah menemui pelbagai jenis seramik yang dikenal pasti antaranya porselin biru putih (blue and white), seladon (Celadon), porselin putih (white ware), porselin hijau putih (Qingbai), tembikar batu bergilap hitam, porselin enamel, lain-lain tembikar batu dan lain-lain porselin. Seramik yang dijumpai ini juga mempunyai pentarikhan yang memberikan jangka masa tertentu di tapak-tapak arkeologi di Sabah. Jumpaan seramik biru dan putih dari China yang banyak di tapak-tapak arkeologi di Sabah menunjukkan bahawa terdapatnya interaksi antara bahagian barat pantai Sabah dengan negara perdagangan maritim yang wujud pada masa dahulu. Hasil analisis menunjukkan perdagangan yang pesat berlaku pada abad ke-15 yang turut disokong dengan kewujudan pelabuhan Brunei dan Banjarmasin yang membawa kemakmuran ekonomi pada zaman itu. Kemasukan banyak kapal dagang yang berdagang di kepulauan Borneo telah menggalakkan aktiviti pertukaran barang dagangan yang penting seperti rempah ratus, seramik, sarang burung layanglayang, hasil hutan dan sebagainya. Oleh yang demikian, jumpaan seramik dagangan di Sabah turut membuktikan bahawa Sabah juga menjadi tempat persinggahan para pedagang untuk menjalankan aktiviti perdagangan. Jumpaan seramik yang banyak di bahagian pantai barat Sabah menunjukkan kemungkinan terdapatnya sebuah pelabuhan atau tempat persinggahan di kawasan itu tetapi kajian lanjut perlu dilakukan bagi membuktikan perkara ini.

\section{PENGHARGAAN}

Sekalung penghargaan terima kasih diucapkan kepada arwah Dr. Jeffrey Abdullah atas segala tunjuk ajar dan nasihat yang diberikan oleh beliau semasa kajian ini dijalankan. Setinggi penghargaan dan jutaan terima kasih juga diucapkan kepada Puan Joana Datuk Kitingan, Mantan Pengarah Jabatan Muzium Sabah (JMS), atas sokongan yang diberikan. Selain itu, ucapan terima kasih kepada Prof. Dato' Dr Mokhtar Saidin selaku Pengarah Pusat Penyelidikan Arkeologi Global atas sokongan yang diberikan. Tidak dilupakan juga kepada staf Pusat Penyelidikan Arkeologi Global dan semua 
MELAYU: JURNAL ANTARABANGSA DUNIA MELAYU JILID 14 BIL. 2 JULAI 2021

staf Bahagian Arkeologi, Jabatan Muzium Sabah yang banyak memberikan kerjasama dan bimbingan sepanjang kajian ini dijalankan.

\section{RUJUKAN}

Andaya, B. W. dan Andaya. L. Y. (2001). History of Malaya. Palgrave Macmillan. Hlm. 1-392.

Baszley Bee Basrah \& Bilcher Bala. (2009). Arkeologi maritim Borneo: Kajian di Tanjung Simpang Mengayau. Universiti Malaysia Sabah. Hlm. 1-228.

Brown, R. 1978. The ceramics of South-East Asia: Their dating and identification (1st Edition). Oxford University Press.

Brown, R. 1988. The ceramics of South-East Asia: Their dating and identification (2nd Edition). Oxford University Press. Hlm. 1-130

Flecker, M. (2013). The maritime archaeological potential of Melaka. John N. Miksic \& Goh Geok Yin (Eds.), Ancient Harbour in Southeast Asia: The Archeology of Early Harbour and Evidence of Inter-Regional Trade, SEAMEO SPAFA, Regional Centre for Archaeology and Fine Art. Hlm 83-92.

Fong C. Y. (1984). VOC relations with Banjarmasin, 1600-1750: A study in Dutch trade and shipping in the 17th and 18th centuries. Hing L.K. (Eds.), The Shipping Lists of Dutch Melaka: A Source of the Study of Coastal Trade and Shipping in the Malay Peninsular During the 17th and 18th Centuries. Kolokium Perdagangan dan Perkapalan Melayu Sebelum 1900. Jabatan Sejarah Universiti Malaya. Hlm. 1-21

Fox, M. S. (2003). A short history of China and Southeast Asia: Tribute, trade and influence. Allen \&Unwin. Hlm. 1-278.

Gungwu, W. (1960). The Nanhai trade: A study of the early history of Chinese trade in the South China Sea. Journal of the Malayan Branch of the Royal Asiatic Society, 31. $1-135$.

Guy, J. (1993). The ceramic of Central Siam. Dlm. Thai ceramics: The James and Elaine Connell collection. Asian Art Museum of San Francisco. Oxford University Press. Hlm. 1-7.

Hall, K. R. (1995). Upstream and Downstream Networking in Seventeenth Century Banjarmasin. Dlm. V.T. King \& Horton, A.V.M. (Eds.), From Buckfast to Borneo; essays presented to Father Robert Nicholl on the 85th anniversary of his birth, 27 March 1995. University of Hull. Centre for South-East Asian Studies. Hlm. 489-504

Hall, K. R. (2010). Coastal cities in an age of transition: Upstream-downstream networking and societal development in 15th and 16th century maritime Southeast Asia. Hall, K. (Ed.), Secondary cities and urban networking in the Indian Ocean realm. Lexington Books: Hlm. 177-204.

Harrisson, T. \& Harrisson, B. (1971) The prehistory of Sabah. Sabah Society Journal, 4, $1-272$. 
Harrisson, T. \& S. J. O'connor. (1969). Excavations of the prehistoric iron industry in west Borneo. Cornell University Southeast Asia Program.

Ipoi Datan. (1998). Santubong. Nik Hassan Nik Shuhaimi (Ed.). Early history: The encyclopedia of Malaysia. Vol. 4. Archipelago Press. Hlm. 112-113.

Karim Osman. (2004). Sungai Limau Manis: Tapak arkeologi abad ke-10-13 Masihi. Jabatan Muzium-Muzium Brunei. Hlm 1- 175.

Ko, J. (2015). The study of Chinese trade ceramics in Sadong River Sarawak (Tesis Sarjana Tidak Diterbitkan). Universiti Sains Malaysia.

Lapian, A. B. (1984). The maritime network in the Indonesian Archipelago in the fourtheenth century. Consultative Workshop on Research on Maritime Shipping and Trade networks in Southeast Asia (I-W7). SEAMEO SPAFA Final Report: Cisarua. West Java. Indonesia. Hlm 71-80.

Lockard, C. A. (2010). The sea common to all: maritime frontiers, port cities and Chinese traders in the Southeast Asian age of commerce 1400-1750. Journal of World History. 21, 219-247.

Metussin Omar dan Shariffuddin, P. M. (1978). Distributions of Chinese and Siamese ceramic in Brunei. Brunei Museum Journal, 4(2), 59-66.

Miksic, J. (2013). Singapore and the Silk Road of the Sea 13000-1800. NUS Singapore Press.

Musa Mohidin., 26 Ogos 2015, Pelita Brunei. Jabatan Penerangan. Tahun 60. Bil 102: 1011.

Nazaruddin Zainun \& Nasha Rodziadi Khaw. (2015). Hubungan ufti China-Dunia Melayu sebelum Masihi hingga kurun ke-11 Masihi: Satu analisis. Dlm. Nazaruddin Zainun, \& Nasha Rodziadi Khaw (Eds.). Perdagangan Dunia Melayu-China hingga kurun ke-16 Masihi. Pulau Pinang: Penerbit Universiti Sains Malaysia.

Nordin Hussin. (2008). Geografi dan perdagangan: Kepentingan Selat Melaka kepada perdagangan dunia. Asia dan Dunia Melayu 1700-1800. Akademika, 73, 3-26.

Othman Yatim. (1978). Oriental ceramic finds in west Malaysia: A study of their distribution and typology (Tesis Sarjana Tidak Diterbitkan). University Durham.

Pitiphat, S. (1992). Ceramics from the Thai-Burma border. Thailand: Sunta Press. Hlm. $1-186$.

Reid, A. (Ed). (1998). Southeast Asian Exports Since 14th Century: Cloves, Coffee and Sugar. Institute of Southeast Asian Studies

Scott, M. M. \& Stratton, C. (1987). The art of Sukhotai: Thailand's golden age from midthirteen to the mid-fifteenth centuries: A cooperative study. Oxford University Press. Hlm. 1-163.

Sukkham, A. (2014). Ayutthayan port town and ceramics trading in southern Siam. Asia Pacific Conference on Underwater Cultural Heritage. May 12-16. Honolulu Hawaii. Hlm. 1-14. 
MELAYU: JURNAL ANTARABANGSA DUNIA MELAYU JILID 14 BIL. 2 JULAI 2021

Taçon, P. S.C., Mohd Sherman Sauffi \& Ipon Datai. (2010). New engravings discovered at Santubong, Sarawak, Malaysia. Sarawak Muzeum Journal, 17(88), 105-121.

Tassim Abu Bakar. (2013). Hubungan Kampong Ayer dengan Kota Batu: Pusat perdagangan dan petempatan penduduk pada zaman tradisi. Jurnal Pendidikan Sains Sosial dan Kemanusiaan, 6(2), 125-134.

Wade. G, (2009). An early age of commerce in Southeast Asia, 900-1300 CE. Journal of Southeast Asia Studies, 40(2), 221-265

Wheatley, P. (1961). The Golden Khersonese. Universiti Malaya Press. Hlm. 1-388. 